\title{
Mending the broken city of Pietermaritzburg through a transformative urban theological programme: A challenge to Union Bible Institute
}

\section{Xolani A. Nkosi ${ }^{1}$}

\section{Abstract}

Rapid urbanisation, globalisation, and the advancement of information and technology come as a challenge for theological education in South Africa, generally, and, specifically, in an emerging city like Pietermaritzburg. This is a city with a multitude of urban fractures: the contesting space between informal traders and the taxi industry; rife political violence; gender- based violence; the spread of HIV and AIDS; and informal housing. This article, in relation to theological education, seeks to imagine curricular changes through using the city as classroom, and collaborating with different community organisations, to help shape our theology for urban ministry. The pastoral praxis cycle (insertion, analysis, reflection, and planning for action) was used in describing these fractures and evaluating the current theological offering. Recommendations for curricular changes that could help to shape our theology for urban ministry in this city are offered.

Key words: urban ministry, Pietermaritzburg, theological programme, Union Bible Institute

\section{Introduction}

Globalisation and rapid urbanisation introduce new challenges for theological education in South Africa. The United Nations Department of Economic and Social Affairs (World Urbanisation Prospect [WUP], 2019), alludes that by the year 2050 the world's population will be 9.77 billion, and 6.68 billion of that population will be living in the urban areas. The rural population will decrease to 3.9 billion by 2050 (WUP, 2018). This reality of urbanisation brings new challenges to developing countries like South Africa. This urban shift will expose fractures that were not considered or realised in the past. A vivid example is the city of Pietermaritzburg. ${ }^{2}$ The increase in gender-based violence, housing shortages, homelessness, the collapse of basic infrastructure due to lack of maintenance, environmental degradation, political crisis associated with kill-

1 Xolani Nkosi is a lecturer at Union Bible Institute in Pietermaritzburg, South Africa. Email: xnkosi@ubi. ac.za.

2 Pietermaritzburg (/,pi:tər'mæritsb3:rg/;Zulu: umGungundlovu) is the capital and second-largest city in the province of KwaZulu-Natal, South Africa. It was founded in 1838 and is currently governed by the Msunduzi Local Municipality. 
ings, substance abuse, the spread of HIV and AIDS and so forth are the portrayers of urban fractures in the city. Hillis (2014:36-40) claims such "challenges can prevent a city from flourishing," further categorising these challenges as "social and spiritual, relationship, resources, leadership, and collective action."

It is therefore imperative for theological institutions to provide a theological education that is relevant, practical and can provide alternatives that will address the multi-dimensional urban fractures. An important step would be for theological education to empower people and open their eyes and see the reality of their context as they minister (Naidoo, 2010). This will call for Bible institutions and seminars to be willing to change their conventional ways of doing theology and commit to developing a new theological curriculum that is more transformative. If theological institutions develop a curriculum that is also transformative, "Church structures will liberate rather than control" (Naidoo, 2016).

This process of transforming theological education will need a total commitment from theological institutions and will be willing to break the status quo to train their students to be liberators. Gutierrez (1973:102) speaking about this commitment, says:

The different sectors of the People of God are gradually committing themselves in different ways to the process of liberation. They are becoming aware that this liberation implies a break with the status quo, that calls for social revolution.

It is for these reasons this paper will discuss transformative ways of doing theology in urban areas to bring transformation to people living in the city of Pietermaritzburg. Hollard and Henriot's (1983) pastoral praxis cycle approach will be used as a broad framework to describe the urban fractures and evaluate the current theological training being offered at the Union Bible Institute. The article reflects on research, exploring the connection between urban ministry and theological education. It will also seek to answer the following question: How can urban ministry and theological education be reshaped through tracing and learning from urban innovations and be able to respond creatively and robustly to deep urban fractures? The objective of the study is to reflect on the role of the Union Bible Institute (UBI) amid urban imperatives and fractures and to suggest a module for the institute. Data was collected through focus groups, interviews, observation, library sources, and newspapers.

\section{Insertion: Encountering the urban fractures in Pietermaritzburg}

Insertion refers to my present experience and action of ministry in response to my context (De Beer, 1998; Kumalo, 2003). I am currently located between a semi-rural/ township and a suburb; these areas are called Mpumuza (Sweetwater) and Hilton 
respectively. These two areas are part of Pietermaritzburg, with movement of people from these two places in and out of the city every day. The semi-rural/township area is not economically viable and for that reason, people flock into the city for work opportunities. The suburban community also goes to the city because their workplaces are located in the city. In 1998, I was sent by my church in Gauteng to go and study theology at UBI in the heart of Pietermaritzburg, which was my entry point into the city.

Pietermaritzburg is one of the highlighted intermediate cities of Kwa-Zulu Natal because of its urban dynamics. It is a city that is a corridor between Gauteng and Durban because of the national road, the N3 freeway. The city is surrounded by townships, suburbs and rural areas. It is a city with a national and international profile because of its history and a city that is a tourist attraction. The city is not large, with a population of less than one million people.

A clear picture of the urban context of Pietermaritzburg is better explained in two faces. These faces will be the official face of the city that is reflected in different documents and the hidden face of the city a reflection of people on the ground.

\subsection{The official face of Pietermaritzburg}

Pietermaritzburg is called a 'City of Choice' and the vision of the city is "a safe vibrant city in which to live, learn, raise a family, work, play, and do business" (IDP 2019/2020). Pietermaritzburg is a legislative city and the capital of Kwa-Zulu Natal. The political system here is represented by the local government connected to the national government. It is connected to churches and the business sector. The city also works with community organizations (NGOs and FBOs). Police stations, City Hall, Courts, and the Fire brigade are strategically positioned near the legislature, near each other.

Above is the official description of the inner city of Pietermaritzburg. However, the real and hidden image of Pietermaritzburg is seen when you enter the city and do critical reading and observe what is taking place downtown in the city. By listening to seldom heard voices of the many people who are marginalised and vulnerable, a different face of the city comes into view.

\subsection{The hidden faces of the city of Pietermaritzburg}

Extending on the previous concern of the city with human struggle, a focus group became instrumental to generate knowledge pertaining to urban fractures. During discussions, it became clear to me that, in most cases the urban fractures are not visible to public eye. It was noted that the issues the residents of Pietermaritzburg are dealing with are diverse and below are a few examples of the issues:

- Difficulty in accessing information

- Emergency services are poor

- Courts are often used as a political battlefield 
- In most departments it is a struggle to get proper and satisfying service

- The public hospitals' service has collapsed, and people wait for more than six hours to get service

It is important to indicate that the above list is not exhaustive in characterising all issues that affect people. However, it is clear that Pietermaritzburg faces daunting challenges and Msunduzi Local Municipality is battling to take care of people coming into the city. Most people moved into the city with a conviction that life in the city would be better, since they would be closer to amenities and economic opportunities that township and rural areas lack. They thought living in the inner city would make all of their basic needs accessible. They thought schools, workplaces, hospitals and clinics, and all necessary services would be nearby, solving a number of problems with transport money and time spent traveling to work and school daily. However, their dream met with the reality of the municipality maladministration that prompted the provincial government intervention. Kaveel Singh (2019) was in the political conversation that led to this statement, "The Msunduzi municipality, where KwaZulu-Natal's capital Pietermaritzburg is located, has been placed under administration following a host of issues, including irregular expenditure, maladministration, and absenteeism by councillors."

Consequently, the absence of proper leadership and administration to stir visions and dreams of citizens the city descended into the phenomenon of anarchy and overcrowding leading to deterioration of basic infrastructure. As a result, urban spaces are increasingly being contested between vulnerable informal traders, and their counterpart formal businesses. The transport industry, taxi industry and private institutions, including churches are under stress. One of the deficiencies in managing the urban space arises from degradation of residential facilities like flats turning into squalid slums. A big squatter camp called ,Jika Joe" downtown is one typical example among others. The Jika Joe community is living in poverty, without proper sanitation and electricity and the place is known as being unsafe. (Msundunzi Municipality, 2015:4). The city is known to be dangerous and unsafe. Here are few crime patterns:

- Violent crime is at a peak in Pietermaritzburg and neighbouring townships. ${ }^{3}$

- The eruption of taxi violence leaving taxi owners, drivers, and passengers. ${ }^{4}$

- Protests against illegal immigrants in the city tend to turn into violence. ${ }^{5}$

3 The Citizen online newspaper reported an incident that took place in the lower inner city of Pietermaritzburg in the Brookside taxi rank. The dispute erupted at the taxi rank over the taxi routes between Howick and Pietermaritzburg and leaving one person dead and several injured (2019).

4 The Citizen online newspaper reported an incident that took place in the lower inner city of Pietermaritzburg in the Brookside taxi rank. The dispute that erupted at the taxi rank was over the taxi routes between Howick and Pietermaritzburg and leaving one person dead and several injured (2019).

5 People are hurt, shops are looted and burnt down. Chantall Presence (2015) in the article "Xenophia attacks spread to PMB" reports that street vendors were robbed by looters on Wednesday as xenopho- 
Consequently, it lacks urban vision and proper governance that paved way for anarchy and chaos to an extent that Khanyile (2020) describes Pietermaritzburg as, "A filthy and stinking city." As she bears witnesses to degradation growing across the city, Khanyile also refers to African National Congress key leaders like Dr. Blade Nzimande and Dr. Zweli Mkhize for failing to facilitate transformation. This lack of leadership to stir up transformation, concerns media reporters like Ntuli (2020:1) who records dilapidated, abandoned, and hazardous buildings surrounding the city. She goes further to warn that, "Health hazard buildings contribute to the grime, urban decay, and the overall decline of the city." These highlighted issues are indicators of fractures in the city, hence I hypothesise that the city is broken and collapsing, and it needs mending.

\subsection{The Union Bible Institute: My entry point to the city of Pietermaritzburg}

The UBI was established in 1939 (Johanson, 1971). Eight Missionary Societies recognised the necessity of a Bible School because Black men and women were already being appointed as evangelists and pastors without adequate bible training in South Africa. The Swedish Holiness Union Mission was approached by the committee and this request was granted, and they were freely given three acres of land to build the school. This is how the UBI was established in Pietermaritzburg. The school was built in a White-dominated area and resulted in a lot of strict rules and regulations that were given to the school governing bodies. These strict rules were given to the school because Black students would be admitted to take up studies (Johanson, 1971).

Rev. A.W.T. Xaba, ${ }^{6}$ former principal of the Union Bible Institute, remembers the rules banning Black staff members and Black students from socialising with White missionary staff members. There were constant inspections to enforce these rules. All this racial distinction was happening in the presence of the school management made up of White missionaries from the USA, Canada, and Australia, and even became neutral towards the apartheid regime policies. Rev. Xaba notes that, the missionaries were afraid to be deported hence their decision was to remain silent. Any discussion about politics was prohibited in class and on the school premises. The staff and students who were likely to talk about the politics of the day were muzzled and the subject matter of the school was limited to the Bible and training pastors.

Rev. D. Mbanjwa 7 asserts that 1968 to 1994 were hard and trying times for Christians and their seminaries. The order of the day was that Black staff and students did not have freedom of speech. They were prohibited to enter White staff houses

\footnotetext{
bic attacks spread to Pietermaritzburg in Kwa-Zulu Natal.

6 Xaba, Albert. 2020. Interview conducted on 6 April 2020. [Personal communication]

7 Mbanjwa, Dumisile. 2020. Interview conducted on 8 May 2020. [Personal Communication]
} 
and were not allowed to socialise with fellow White colleagues. Although the school was in a close proximity to a township, which was an ongoing site of resistance, the institution did not allow its students to join other institutions of higher learning for protests and dialogues because of fear. The classes at UBI continued but the tension in the school was tangible since students were not comfortable because of what was happening and what they were witnessing in the township. Some of the students suspecting some White missionaries were supporting apartheid; hence, the school was not confronting the regime and allowing students to participate in the armed struggle.

Although the institute was not directly affected by the war in the township it might have at least made a statement to condemn the oppression that was taking place during the time of apartheid. In addition, attempts could have been made to encourage and advocate for peace amongst the community members despite their political and ideological differences, but the institute missed that opportunity to have a voice and nothing was recorded about UBI during the prolonged state of oppression.

Unlike the painful closure of the Federal Theological Seminary of Southern Africa in 1993 (Denis, 2009), the UBI survived the unbearable years of oppression and it is still offering theological education. However, the reality is that the times are changing, and the institution must be alert, be able to read the signs of the times and be able to take strategic decisions.

As in the past, tensions in society from rapid urbanisation may remain unrecognised. Noticing the fast pace of an urbanising world and the reality of urban imperatives, the UBI could be impelled to have a different latitude of theology as advocated by Davey (2001:11).

Looking in depth at the above theological orientation, an institution like UBI that was affected by political history and racial segregation is challenged. In this respect, there are critical questions one should ask: 1) What is the role of UBI in South Africa today? 2) What is the role of UBI in a city like Pietermaritzburg that is engulfed by violent crime, poverty, gender-based violence, maladministration, and social decay? 3) How can one foster a new urban theological vision in an institution like UBI that is more than 76 years old?

\section{Analysis: Relevancy of theological education in the City of Pietermaritzburg}

This section set out to present a reflection on the discussion that took place in the focus groups and also my observation as a practitioner and educator. The City of Pietermaritzburg has drastically changed since the founding of UBI in 1994. The rich minority moved out of the central business and residential district and the poor 
majority moved to the central business district with the hope of a better life. Since the democratic transition, the conditions under which people have to live in the city can be best described as a constant struggle for survival (Kumalo, 2003). The population is ever-growing in the inner city, currently at 228133 people, projected to grow over the next $30-40$ years (Msunduzi Municipality, 2015). The city's largest population is the youth, and this has huge implications for town planners. The Town planning will, therefore, need to include appropriate recreation, entertainment, education, and employment opportunities (United Nation Population Division, 2010). A municipality or higher education institution that does not have a proper plan on how to accommodate its youth can expect to experience a lot of chaos. South Africa has witnessed this through the "Fees must Fall" protests in 2018, the xenophobic attacks since 2008, and with the youth uprising in 1976.

In Pietermaritzburg, women ${ }^{8}$ make up a larger percentage of the population and they are the primary breadwinners at home (Local Economic Development, 2014). With the lack of employment opportunities, most of them do odd jobs and are employed in the informal sector. A lot of women work as informal traders, domestic workers, work in saloons (hair, bars, clubs, and food outlets), in shops, petrol stations, or work as security guards and cleaners. These occupations are not well-paying and in some cases exploitation, abuse and harassment are common so that women are victimised and forced to bear pain and abuse to make ends meet.

One other challenge in Pietermaritzburg is the cultural practice of patriarchy in the culture of the Zulu people, where a man is raised to be the leader and head of the family, in such a manner that the male is trained to be strong and in the forefront to control and to impose discipline in the family. According to Gennrich (2004:1416), men turn to violence to prove their dominance over women, and as a result, a lot of women and children became victims of domestic and gender-based violence. Some are displaced and homeless or some are driven to shelters in the city.

The rapid spread of HIV and AIDS in the province of Kwa-Zulu Natal ${ }^{9}$ is one of the social challenges that impact Pietermaritzburg negatively. Amongst the contrib-

8 In Pietermaritzburg, 33\% of the population are 20 years of age, 39\% are between 21 and 40 years, $41-60$ years are $19 \%$ and $9 \%$ are 61 and above. Males make $47 \%$ of the population and females $53 \%$ of the population.

9 "KwaZulu-Natal remains the province with the highest number of people living with HIV in South Africa. This was revealed by a recent study conducted by the Human Sciences Research Council. While it showed some improvements in the province's AIDS response, it also highlighted many challenges that exist. Results of the survey show that there are now 7.9 million people living with HIV in South Africa. Over 2.1 million of those are in one province, KwaZulu Natal. Professor Quarraisha Abdul-Karim from Comprehensive International Program of Research on AIDS (CIPRA) reiterated that HIV prevalence is concentrated in some parts of the province especially in the Mgungundlovu district," https://www. sabcnews.com/sabcnews/kzn-remains-province-with-highest-number-of-people-living-with-hiv/. 
uting factors to the spread of the virus are the patriarchal system, cultural marriage practices - [ukulobola,${ }^{10}$ ukungenwa, ${ }^{11}$ and ukuthwala, ${ }^{12}$ ] myths about male sexuality and men's sexual needs, migrant labour and violence towards women. (Ibid). All these issues need to be addressed theologically by the church.

Considering all the above issues in the city and the whole uMsunduzi Municipality, the ministry of the church will have to be comprehensive in its approach, addressing both the spiritual and material needs of people.

In my years as a minister and educator, I have witnessed churches dying and mission failing because their approach to certain communities was not successful. It is either that they disregarded the real issues that were affecting that particular community or they were too comfortable and they lost their prophetic voice. It is therefore imperative for any church that wants to be the salt and light to its urban community to be willing to reflect on the effectiveness of their programmes and be willing to take risks and pay the price as per the assertion of Pityana and VillaVicencio who historically called the church to action.

The call to prophetic ministry requires the church to be both a social critic and a partner in the building of the nation. At times the church will be required to pay a heavy price for rendering this ministry. At times it will receive national acclaim. It is required theologically to never allow itself to be seduced by either (Pityana \& Villa-Vicencio, 1995:50).

The church's programmes are supposed to be contextual and meet the spiritual, emotional, and material aspects of a person. The ministry of the church will involve the preaching of the gospel, Christian service, and the development of communities (Kumalo, 2003).

\subsection{Theological education and urban imperative}

De Beer (2012:273), speaking about theological education and its curriculum in the University of Pretoria states, "The theological faculty has to consider preparing students more deliberately for the range of urban contexts in which they will find themselves ministering." This means the training of ministers must not only be focussed on the theory, but the training must be all-inclusive and holistic. After completing their

\footnotetext{
10 "ukulobola" - paying a huge bride price, this could either be money or cows depending on what the family of the bride ask for. In some instances, this could make the husbands feel as if the wife is his property to be used as he pleases.

11 "Ukungenwa" - when the elder brother dies, the family expect the younger brother to take over and marry his brother's widow. In many instances, the woman is forced to marry or else she will lose everything - children and her husband's inheritance.

12 "Ukuthwala" - it is when a young lady is abducted and forced into marriage.
} 
theological studies, ministers must be able to engage different groups of people in different situations and circumstances. This is also a challenge for the UBI, Evangelical Seminary of Southern Africa and Seth Mokitimi Methodist Seminary to consider the curriculum they are offering to adjust it to be responsive to the current context.

The process will call for radical changes in theological development and education. For it is a known fact that most theological education offered in most of the old institutions is brewed in the western pots. The textbooks that are offered to students are written in the context of scholars from the west. Hence, in most cases, such education cannot be responsive to the realities of an urbanising Africa. As an educator at the UBI, I have noticed that students use textbooks written by western scholars because they are the mostly prescribed. Maluleke (2006:66) alludes to this fact that "even today, it is still possible to attain a diploma or a basic degree in theology within Africa and to do so without having ever read any work by an African." It is for this reason that many South African ministers will address African issues using western theories and philosophies and to their surprise, the theological formation and tools fail to address the African urban context.

The context and the settings in the urban areas are different and therefore the theological education and formation of ministers in cities and the urban areas should be constructed differently. The processes of developing this theology must "come from communities and individuals familiar with much of this from daily experience from people understanding this present, speaking of it, when the reality is sometimes denied ..." (Davey, 2001).

Since the city has ever-changing challenges and a complex context, any organisation or church that senses a call to serve in the city should be ready to contextualise its ministry. In the Lutheran World Federation 2004, we read that:

God's mission as contextual, addressing faithfully the challenges of ever-changing and complex contexts and it is comprehensive and holistic. The mission is holistic and contextual concerning its aim, practice, and location. Its aim encompasses the whole of creation (ecological concerns), the whole of life (social, political, economic, and cultural), and the whole human being (i.e., all people and the whole person - spiritual, mental, relational, physical, and environmental needs). Its practice calls for the participation of the whole church, women, and men, young and old. Being holistic, mission flows from the being of the church as worshipping, messenger, serving, healing, and oikumene community.

This phenomenon will require those faith communities, churches, and the leaders who are empowered accordingly and "to discern the will of God for their situation" (Mbewe, 2002:3). When the congregation now understands their situation, they 
will have to "describe their situation and correlate that situation with the faith and belief of the congregation (Ammerman et al., 1998:25). At this point, the church will be able to draw programmes that are contextual and comprehensive, where their liturgy, sermons, and programmes will address the situations of their context. This practical theology approach of doing ministry will always reflect on the training the pastor/priest of the church/congregation received when s/he was at seminary. If the priest/pastor was not trained in contextual ministry, situation analysis, or introduced to the praxis cycle and understanding the urban congregation, the contextual and comprehensive ministry in the city will not thrive.

A critical reflection on the curriculum of theological institutions is necessary. According to Bevans (2004:3), "There is no such thing as theology, there is only contextual theology." Bevans is precise because every form of theological education has a background, situation, and a framework. Ogouk and Smith (2018:np) assert, "Recognition that all theology leads us into the broad question of what the process of contextualisation looks like." Consideration must be given to the needs, interests, reality, and language of our audience as we are planning to minister to them. This process drives institutions and churches to ask more questions rather than giving answers to everything. It will also require institutions and churches to switch positions from being the experts to allowing students and the communities to teach them their reality and learn from their context before planning for ministry or developing their theology curriculum.

\subsection{Theological education and city intermediaries}

Homelessness, HIV and AIDS, land issues, unemployment, substance abuse, teenage pregnancy, gender-based violence, and violent protests are the new urban realities and imperatives. These realities are forcing the theological education system to be more versatile, and open to new ways and methods of doing theology in the cities and urban areas. This may call for a theological institution to be open to learning from people and organisations that were never imagined contributing to theological education. Today, some of the leading movements bringing healing and justice in South African cities are social movements. These movements addressed issues that churches and theological institutions may not be comfortable to address. They are addressing issues of homelessness, HIV and AIDS, land, and many other issues. There are several social movements operating in Pietermaritzburg:

- Abahlali baseMjondolo is a large social movement claiming to have 30000 followers from 30 informal settlements mostly in Durban as well as in other cities throughout South Africa. Their focus is to engage the government on matters concerning land, housing in the city, forced removal, access to water, electricity, 
refuse removal, health care, and education. They also challenge non-governmental organisations claiming to talk for the poor (De Beer, 2017).

- The Treatment Action Campaign gave HIV and AIDS a new identity in 1998 in South Africa. The organisation is known for awareness-raising and supporting those infected and affected by HIV. It also won a court case that forced the government to start rolling out antiretrovirals (Treatment Action Campaign, 2020).

- The Built Environment Support Group (BESG) was established in 1983 as a support group that defended communities against eviction from informal settlements in urban areas. BESG became a key player in shaping planning and housing policies from local to national levels. Since 1995, BESG has been a leader in enabling poor communities to access land, basic services, housing, and administrative justice (BESG n.d).

- The Pietermaritzburg Agency for Christian Social Awareness is a 40-year organisation that encouraged communities to stand in solidarity to end apartheid. Postapartheid, they have been involved in the process of democratisation of South Africa by offering training and development of communities and autonomous grassroots organisations (PACSA, 2018).

- Project Gateway was formed in the late 1980s in a time of intense political turmoil in the Pietermaritzburg area. Pastors from various churches knew that the church could not ignore the situation, and Project Gateway was formed as a response to the immense need that surrounded them (Project Gateway, 2020).

- Church Land Programme (CLP), established in 1997 with its focus on church land while also encouraging the church to engage in issues concerning the national land question (CLP, n.d.)

\subsection{Strategising for missions and transformative development}

Often churches enter a community and assume that they will bring answers to their challenges without a strategy for the mission they want to execute. As a result, churches fail or are rejected by the community. Three years ago, a group of students from the UBI were doing their evangelistic campaigns in the city. They visited the informal settlement Jika Joe to preach but unfortunately, they were violently chased away from that community. Students were traumatised by the incident and were blaming the devil and demons. To my surprise, no-one amongst them said maybe our mission strategy was not pertinent for that community. This was supposed to be a lesson for them but unfortunately, valuable understanding was missing.

As I was reflecting on the incident, I realised that on both urban areas and in cities, communities are not homogenous but a combination of different groups of people with different issues and challenges. Therefore, strategising for missions is not an option. According to Ntshumayelo (2005), "Networking, community organising, mission, incarnational mission, understanding the community, the need 
for evaluation, and developing a holistic ministry" are necessary. For communities such as Jika Joe, it is important to have a strategy that will also address their current situation. Any missional work must be accompanied by the development and practical implementation of the gospel (Kumalo, 2003). Constant monitoring and evaluation of work are essential, first evaluating our relationship with a community. Theological educators must ask critical questions such as 1) Do we know the community we are working with? 2) Have we learnt from them? 3) Are we scratching where it itches?

\section{Reflection: A contextual theological education for a South African city - Pietermaritzburg}

Theological education was a great need for Black South African pastors in the past seventy to eighty years. It is for this reason UBI was established, to provide training for Black evangelists and pastors in South Africa. The mandate of UBI was clear and relevant for that context and the focus of the training was to prepare them for leading and pastoring churches. Since the establishment of the UBI in 1939, drastic changes took place and the face of education and training has changed. There are also new challenges for the current context. It is important to offer an education that will be able to address the current situation.

The kind of theological education for the city should go beyond the conservative methods of teaching theology. De Beer (2012:260) asserts that the city "requires a theological education that is probably way beyond what is traditional models of theological education ..." My theological imagination for Pietermaritzburg, Msunduzi municipality, is a theology that can offer alternatives. A theological formation that will enforce and advocate for social justice and equality, especially in a society where women and poor people are treated as objects not as subjects and community education. I also envisage that the theological institutions in the Pietermaritzburg cluster for theological institutions have a continuous reflection on the theology that they are offering in their institutions. I would also like to see my institution, UBI, constantly reflecting on its theological offerings as well, and this theology must be contextual and prepare students for the urbanising and technological advancing future of Africa.

Community empowerment is one of the essentials needed for the community of Pietermaritzburg, Msunduzi municipality. This process of empowerment must not create a paternalistic attitude but promote self-reliance and self-sustenance of the community. The focus here shifts from a need-based approach to the assets of a community and encourages community cohesion, hospitality, and sharing of resources (Kumalo as cited in Dreyer et al., 2017:29). It is searching and unveiling hidden dreams, talents, and skills and using those to develop a community sustainably. 
Community education is essential for poor and vulnerable communities. This is an education that will be an instrument to emancipate the community, unlike the Bantu education that kept a Black person as a slave and a White person as a master. However, an education that will bring self-awareness, where oppressed people will seek to be freed so that they will recognise the condition in which they find themselves is inappropriate (Reddie, 2003). The nature of this kind of education will not maintain the status quo but will bring social transformation. All of this will depend on who is in our frame of reference and if we are willing to make education in the community to be an interdisciplinary collaboration (Seymour, 1997). The education in a community must be for the community (Palmer, 2001) and this means those in the community are being transformed and the process is done collaboratively. This model of education relates to the context of the community and focuses on converting the world through an emphasis on missiology (Banks, 1999). This means when the community is first educated, and their appalling context is in the process of transformation then they can be catalysts of change in the whole world and use their own stories and struggles as a testimony to others.

A new theological education for the communities will require intentional partnership. A partnership is "sharing with another or with others in action," it is "demonstrated by a commitment of trust, demonstrated by a readiness to serve the purpose of the focus of the partnership and a readiness to pay the price of partnership" (Warren, 1956:12-13). The definition by Warren gives us a clear picture that partnership is an action, and willingness to sacrifice. Kari Jordheim as cited in Dietrich et al., (2014:194) states, "The role [of partnership] is to serve people in need, to be among as one who serves, to participate in God's love for the whole creation and further God's reign." It demands that the people working together have one purpose and goal. Bush and Lutz (1990:46) describe the partnership as "an association of two or more autonomous bodies who have formed a trusting relationship and fulfil agreed-upon expectations by sharing complementary strengths and resources, to reach their mutual goal." This is a challenge for most Christian organisations since they are not willing to be in partnership with other organisations or they are choosy about who they want to work with. For example, the UBI is not part of the Cluster for Theological Colleges in Pietermaritzburg. Their reason for the lack of interest in participating in the cluster is that some of the colleges are not teaching evangelical theology but liberal theology. My criticism of this mentality is that colleges, which operate in isolation, miss several opportunities such as the sharing of resources, knowledge, exposure, and learning together. My recommendation regarding this partnership it is to see UBI working with the Cluster for Theological Colleges in Pietermaritzburg to develop an urban ministry course. 


\section{Planning for action: Theological imaginations for the city in a South African context}

Fostering new theological imagination will not be possible until we realise and acknowledge that Pietermaritzburg, Msunduzi Municipality, is broken and the brokenness is revealed in different ways.

- It appears as if there is nothing wrong with gender inequality, male chauvinism, domestic violence, and gender-based violence. At times these abnormalities are prompted by culture and religion.

- Violent crime taking place in the suburbs and townships (the violent raping of children and elderly people, housebreaking, hijackings, looting of foreign national's shops during the scourge of xenophobia, violent protests).

- Corruption and maladministration in some government departments leading to the whole Msunduzi municipality being placed under an administrator.

- The appalling state of the city's dilapidated buildings, damaged roads, filth on the streets, and neglected space that can be used for recreational purposes.

- Political intolerance that is so rife and leading to the death of officials and politicians.

- The scarcity and limitation of resources, the party politics, different institutions operating in isolation, influx of people and congestion contribute to this complexity of the cities.

The above issues have been presented in earlier discussions and these are indications that hopes for the future of the community of Pietermaritzburg has been compromised a great deal. People have no sense of security and assurance about democracy. Hence some community members do not even go to vote during the elections. To mend a broken city new imagination will need to be fostered:

1. The practice of - personhood and human dignity.

2. Diaconal ministry - a Christian social practice.

3. Social justice - to act justly, love tenderly, and walk humbly with our God.

However, this will also call for theological institutions like the UBI and the others to think of a curriculum that will bring effective community transformation for cities. Wahl (2013) argues that the African cities' context is always changing, and it demands relevant theological education that will develop competent church leaders. It is therefore important for a theological institution's curriculum to provide alternative frameworks for the theological education and this will include the following:

\subsubsection{Access}

Access to theological education is always a challenge for ministers in South Africa and other developing countries (Wahl, 2013:269). The African Independent Church's rate is 
growing rapidly in Africa and $50 \%$ of their leaders have no form of theological education (Wahl, 2013). The contributing factors are that these churches were not recognised and were therefore discriminated against (Ibid: Wahl). Hadebe (2017:2-9) argues that commodification of education is one of the factors that contributes to the lack of access to theological education for African ministers who lack resources. The UBI is one of the institutions that still tries to make its theological education affordable in order to be accessible to pastors from poor backgrounds. The fees structure of the UBI is lower compared to the fees of other theological institutions in Pietermaritzburg. Another barrier to the access to Theological Education is the language barrier for ministers in the African Independent Churches. Since most of these churches are from the rural areas and townships most of the ministers did not even reach Grade 12 and they cannot fully express themselves in English. Fortunately, the UBI is uniquely offering their theological training in the isiZulu language, making it accessible to ministers that are not fluent in the English language. However, the ongoing challenge is to always design a curriculum that is relevant to a particular context and especially in the era of rapid urbanisation.

\subsubsection{Context}

By context, we refer to the "whole environment in which the people of God live, that includes social, economic, educational, religious, philosophical and political ..." (Gehman, 1987:80). The fragmented character of the city calls for the UBI to be intentional when designing a curriculum that will address the city's context. This kind of a curriculum must not just be an abstract document and it should not be designed by a group of professionals who have no clue of the urban realities. Designing this curriculum should be a process that involves the professional, clergy, laity and the community and individuals. Considering that the urban realities of Pietermaritzburg affect all those who live in the city, the theological curriculum and theological education should also be for "the whole people of God in the city" (Pazmino, 1997:11). An example of this is seen in Prof. Bongani Mazibuko who made theological education public by starting Umlazi Project and aiming to teach theology to Ministers of African Initiated Churches (Mazibuko, 2005). This kind of theological education that was offered to these ministers was contextual because Mazibuko was convinced that education should bring liberation. He argued that the Church must contribute to the education of a society and higher learning institutions must partner with local communities for mutual teaching and learning (Mazibuko, 2003:272).

\subsubsection{Contents}

In most cases, the contents and themes of the curriculum of theological institutions is derived from books and manuals. However, the contents and the themes of a curriculum that will address the urban realities should be derived from people. Ku- 
malo (2005:216) asserts, that "From the themes raised by people, a transformedcentred curriculum can be constructed." Therefore, the people in community will be the best platform to enumerate and show the problems and the wounds of the city and from these conversations, themes for the curriculum will be derived. The UBI must be able to identify the concrete community felt needs of their local people and their constituencies. This process will involve consultative meetings with local people and the UBI constituencies. All the themes that are raised in the meeting will be listed together at first and a second list of prioritised themes will be drawn up and a curriculum developed.

\subsubsection{Curriculum}

According to Bertram (2000:13), a curriculum is "the content, the pedagogy and the evaluation of education." The UBI does not use the term curriculum but rather uses the term syllabus. The syllabus is an outline describing the course, the outcomes, assessment processes, textbooks and other learning materials, and the due dates for assignments, exercises and tests. To have a curriculum is important for an institution but the curriculum should not dictate the learning processes but rather be a guiding document that will be "flexible to allow changes that might be needed in the process" (Kumalo, 2005:219).

A challenge for the UBI is to develop a holistic curriculum that will "seek to engage the heads, heart and hands of participants in transformative ways" (Pazmino, 1997:9). For more than seventy-six years, the UBI is renowned for giving theological knowledge to its students and challenges them to live a life worthy of their calling as ministers. However, the curriculum was lacking in terms of encouraging students to participate in transforming the society and a typical example was the silence of the students of the UBI during the armed struggle in the 1990s. Therefore, the proposed curriculum for the UBI will seek to engage not only the heads and hearts of students but also their hands to participate in the transformation of a nation. Banks (1999:144,169-181) developed a missional model approach for curriculum design. The main emphasis of this model is to have a "relationship between action and reflection and theory and practice." Taking from the model of Banks, the following curriculum is proposed for the UBI:

- Course - Church in an urbanising society.

- Course description - This course investigates what it means to be Christian in South Africa today. It seeks Christian responses to societal challenges of andragogy and other forms of adult learning; inclusive, exclusive and transformative education; gender, issues of development and underdevelopment; crime and violence and a Christian response to rapid urbanisation. 
- Expected outcomes - At the end of the course the student will understand how issues studied have a major impact on the development of cities, take appropriate action in dealing with those issues from a Christian perspective and develop tools that could be used to address social challenges and urban imperatives.

- Course content:

- A Biblical basis for social engagement

- The church struggle in South Africa

- Andragogy and other forms of adult learning - a challenge for the church

- Transformative education for the youth in the cities

- Being a missional church in an urban world

- The social construction of gender and the impact of sexism in the South African church

- Christianity and economics, some Biblical foundations

- Theology and development

- The problem of poverty and pandemics in South Africa

- Crime and violence in South Africa

- Advocacy, lobbying and participation

\section{- Course assessment}

All students are expected to do a critique of a book (discuss the title with lecturer) and present their findings in class. Students must also identify an FBO or an NGO that is involved in community development and be mentored in that organisation for the duration of the course. At the end of the course, submit a final report on what they have learned, unlearned and relearned.

\section{- Course duration - One Semester}

The UBI will also be challenged to look for strategic partners and to strengthen its relationship with FBOs, NGOs and Civil Organisations. This will help the college to continue offering theological education that is more affordable and accessible. More people will be equipped and benefit from learning about relevant issues that affect them daily. More people will take leadership and be change agents and the cities will be healthy, good and flourishing places. According to (Tyler, Ortegon \& Ramirez, 2013), an example of a flourishing city is: 1) A courteous city - civil, wellmannered, and welcoming city; 2) An active and inclusive city - all people have equity, can dream, and use their skills and talents, and their needs are met; 3) City as public space - public space is designed in a manner that every person has access, is safe and protected, and people have a sense of belonging; 4) A healthy city - ensuring health and hygiene for all people and preserving the environment for the future generation; 5) An evolving city - a developing, and progressing city, the city's plans and programmes are designed in such a way that they are flexible and can allow innovation to take place. A sixth character can be added; 6) A celebrat- 
ing city - a city where everyone is allowed to be different and unique and diversity can be celebrated openly through parades and different festivities like the "Feast of the Clowns" organised by Tshwane Leadership Foundation (2016) in Pretoria, Tshwane.

\section{Conclusion}

Continuous engagement, dialogue, and reflection amongst communities that share the same concern, pain, and have the same vision will be necessary for an urban theology that will make a difference in the city of Pietermaritzburg. Community collaboration will continue as long as the city is not completely rehabilitated and developed. There must always be constant engagement with theological institutions regarding their curriculum in deeper connection with communities. In my institution, I will advocate for the curriculum that will facilitate the building of flourishing African cities. Learning can and should be a shared effort where students and teachers construct new knowledge together.

\section{References}

Ammerman, N., Carroll, J.W., Dudley, C.S., \& McKinney, W. 1998. Studying congregations. Nashville: Abingdon.

Banks, R. 1999. Reenvisioning theological education. Grand Rapids: Eerdmans

Bevans, S. 2004. Models of contextual theology. Orbis: New York.

Bertram, C. 2000. Curriculum studies. Pietermaritzburg: University of Natal. Built Environment Support Group. n.d. Available from: https://www.besg.co.za/ (Accessed 5 July 2020).

Bush, L., \& Lutz, L. 1990. Partnering in ministry: The direction of world evangelism. Illinois: InterVarsity Press.

Church Land Program. n.d. Available from: http://www.churchland.org.za/?page_id=413 (Accessed 5 July 2020).

Davey, A. 2001. Urban Christianity and global order: Theological resources for an urban future. London: Society for Promoting Christian Knowledge.

De Beer, S. 2012. Urban South Africa: An opportunity for liberating theological education. Missionalia: Southern Africa Journal of Missiology, 40(3), 251-277. https//doi. org/10/7832/40-3-32.

De Beer, S. 2017. Urban social movements in South Africa today: Its meaning for theological education and the church. HTS Teologiese Studies/Theological Studies, 73(3), a4770. https://doi. org/10.4102/hts.v73i3.4770.

Denis, P. 2009. Unfinished business: The painful closure of the Federal Theological Seminary of Southern Africa. Missionalia: Southern Africa Journal of Missiology, 37:1, 5-19.

Dietrich, S. (2014). Reflection on core aspects of diaconal theory in Dietrich, S. (et al).Diakonia as a Christian social practice: An introduction. UK: Regnum Books International. Gehman, R.J. 1987. Doing African Christian theology: An evangelical perspective. Nairobi: Evangel Publishing House. 
Gennrich, D. 2007. The Church in an HIV+ world. Pietermaritzburg: Cluster Publications. Gutierrez, G. 1973. A theology of liberation. New York: Orbis Books.

Hadebe, N.M. 2017. Commodification, decolonisation and theological education in Africa: Renewed challenges for African theologians. HTS Teologiese Studies/Theological Studies, 73(3), a4550.

Hillis, D.C. 2014. Cities: Playground or Battleground. USA: Leadership Foundation Press.

Hollard, J., \& Henriot, P. 1983. Social analysis: Linking faith and justice. NY: Oribis books Maryknoll.

Johanson, B. 1971. We watched it grow: A story of the Union Bible Institute. Sweetwaters: Union Bible Institute.

Khanyile, N. 2020. Msunduzi: Home of filth and stink. The Witness, 1.

Kumalo, S.R. 2017. The changing landscape of South Africa and complications for practicing ubuntu. In Dreyer, J., et al. 2017. Practicing ubuntu: Practicing theological perspectives on injustice, personhood and human dignity. Zurich: LIT VERLAG GmbH \& Co. KG Wien.

Kumalo, S.R. 2003. From desert to forest. Pretoria: CB Powel Bible Centre.

Kumalo, S.R. 2005. Theology and education: The role of the church in education for social transformation: A Methodist contribution. PhD thesis. University of KwaZulu Natal.

Mahlokwan, J. 2019. Feast of the clowns set to raise laughs, Pretoria News. Available from: http://tlf.org.za/news-article-feast-of-the-clowns-set-to-raise-laughs/ (Accessed 2 April 2020).

Maluleke, T.S. 2006. The Africanization of theological Education: Does theological education equip you to belp your sister? In E.P. Antonio (ed.), Inculturation and postcolonial discourse in Africa, pp. 61-76. New York: Peter Lang Publishing Inc.

Mazibuko, B. 2003. Education is Liberation. In Gerloff, R. Mission is Crossing Frontier: Essays in Honour of Bongani A. Mazibuko, Pietermaritzburg: Cluster Publication.

Mazibuko, B. 2005. The Umlazi Project as a Case Study in Liberation Education. In Gerloff, R.

2003. Mission in crossing frontiers: Essay in honour of B. A. Mazibuko. Pietermaritzburg: Cluster Publication.

Mbewe. 0.L.J. 2004. Urban poverty as a challenge for urban ministry within the Malawian context. $\mathrm{PhD}$ thesis. Stellenbosch University.

Mbovu, N. 2015. Living in constant fear of attack in Pietermaritzburg. Available from: http:// groundup.org.za/article-print/living-constant-fear-attack-pietermaritzburg_2848/ (Accessed 28 April 2020)

Merret, C. 2013. A small civil war: political conflict in the Pietermaritzburg region in the 1980s and early 1990s. Natalia 43 (2013), Cristopher Merrett pp. 19-36.

Lutheran World Federation. 2004. Mission in Context: Transformation, Reconciliation, Empowerment. An LWF. Contribution to the Understanding and Practice of Mission. Switzerland: The Lutheran World Federation. Msunduzi Municipality. 2015. Informal settlement: Jika Joe. Pietermaritzburg.

Naidoo, M. 2010. Ministerial training: The need for pedagogies of formation and of contextualisation in theological education. Missionalia: Southern Africa Journal of Missiology 38(3), 347-368. 
Naidoo, M. 2016. Liberative black theology: A case study of race in theological education. ActaTheologica, 36(Suppl.24),157-177.

Ntuli, N. 2020. City guns for 'bad buildings'. The Witness, 1.

Ntshumayelo, M. P. 2005. Developing a mission strategy. Available from: https://repository. up.ac.za/bitstream/handle/2263/29093/06chapter6.pdf?sequence=7\&isAll owed=y (Accessed 22 February 2020).

Oguok, S.O., \& Smith, C. 2018. The informal God: Outside school of In S. de Beer (ed.), Just faith: Global response to planetary urbanisation. HTS religion \& Society Series, 3, 223-252.

The United Nation Population Division. 2010. Development and Population. Available from https://www.un.org/en/development/desa/population/publications/pdf/trends/ WPP2010/WPP2010_Volume-I_Comprehensive-Tables.pdf (Accessed 6 June 2020).

The Msunduzi Local Municipality's Local Economic Development (LED) Strategic Plan. 2014.

The Msunduzi Municipality: Pietermaritzburg. Available from: http://www.msunduzi.gov.za/ site/home/index.html

United Nations, Department of Economic and Social Affairs, Population Division (2019).

World Population Prospects 2019: Data Booklet (ST/ESA/SER.A/424).

Pietermaritzburg Agency for Christian Social Awareness. 2018. Elementor. Available from: https://pacsa.org.za/index.php/elementor-1500/ (Accessed 5 July 2020).

Palmer, P. 2001. The courage to teach. Michigan: Josseyp-Bass.

Pazmino, R. W. 1997. Designing the urban theological curriculum. In Perry G. Downs (ed.), Christian Education Journal, 1(2). USA: Trinity Evangelical Divinity School.

Pietermaritzburg, Msunduzi Municipality. Available from: http:/www.msunduzi.gov.za/site/ search/downloadencode/intergrateddevelopmentplan2019/2020financialyear.pdf (Accessed 24 January 2020).

Pityana, N., \& Villa-Vicencio, C. 1995. Being the Church in South Africa today. Cape Town: Worldsmith.

Presence, C. 2015. Xenophobia attacks spreads to PMB. Available from: http://iol.co.za/ news/xenophobia-attack- spread-to-pmb-1845704 (Accessed 28 April 2020).

Project Gateway. 2020. Strategic plans. https://www.projectgateway.co.za/ (Accessed 5 July 2020).

Reddie, G. 2003. Developing a black Christian education of liberation for the British Context. Religious Education, 98(2), 244-264.

Seymour, J. 1997. Mapping Christian education. Nashville: Abingdon Press

Singh, K. 2019. Msunduzi Municipality in KZN placed under administration Available from: https://www.news24.com/SouthAfrica/News/msunduzi-municipality-in-kzn-placedunder-administration-20190409 (Accessed 29 April 2020).

The Citizen. 2019. Watch: PMB under siege as taxi violence erupts. Available from: http:// citizen.co.za/news/news-cns/1943325/watch-pmb-under-siege-as-taxi-violence-erupts (Accessed 28 April 2020).

Treatment Action Campaign. 2020. About. Available from: https://tac.org.za/category/about/ (Accessed 5 July 2020). 
Tshwane Leadership Foundation. 2016, http://www.tlf.org.za (Accessed on the 5 July 2020). Tyler, N., Ortegon, A. \& Ramirez, C. 2013. Proposal for a National Transport Strategy for low carbon cities: Colombia in 2030. Colombia: s. $\mathrm{n}$.

Wahl, W.P. 2013. Towards Relevant Theological Education in Africa: Comparing the International Discourse with Contextual Challenges. Acta Theologica, 33(1), 266 293.

Warren, M. 1956. Partnership: The study of an idea. London: SCM Press Ltd. 